\title{
Structural and hydrological controls on the development of a river cave in marble (Tapagem Cave, SE Brazil)
}

\author{
William Sallun Filho ${ }^{1,2^{*}}$, Bruna Medeiros Cordeiro' ${ }^{2}$, and Ivo Karmann ${ }^{2}$ \\ ${ }^{1}$ Geological Institute, State of São Paulo Environment Department, Rua Joaquim Távora, 822, 04015-011, São Paulo, SP, Brazil \\ ${ }^{2}$ Geosciences Institute, University of São Paulo, Rua do Lago, 562, 05508-080, São Paulo, SP, Brazil
}

\begin{abstract}
Tapagem Cave (or Devil's Cave) is a river cave developed in the dolomite marble karst of the Serra do André Lopes (State of São Paulo, southeastern Brazil). Although this region is a plateau with significant variation in elevation and a humid subtropical climate, the cave is an anomalous feature in the André Lopes karst because there are few other caves. The marble, which is in a synclinal structure with subjacent phyllites, is a karst aquifer perched above the regional base level (Ribeira River) and has little allogenic recharge. The cave developed on a secondary anticline on the northwest flank of the marble synform forming a blind valley, the Tapagem River sink, that is an underground tributary of Ostras River. Development of the cave is due to the entrenchment of the Ostras through-valley and the large allogenic catchment area of the sink. In plan view, the morphology of the cave can be divided into three different sectors. The first sector, known as the Tourist Sector, has extensive collapse rooms, fossil passages and a variety of speleothems of notable dimensions. The second and most extensive sector is the river passage, which is a sinuous gallery controlled by marble banding with NE-SW cleavage and NW-SE fractures. In cross-section, the passages are vadose canyons up to $70 \mathrm{~m}$ in height, controlled by the marble banding. Four NW-SE diabase dykes in this passage do not affect its direction in plan view. The third sector is an extensive network of passages and collapse rooms, which are interlaced in plan view and on different levels, forming a maze pattern. Initially, the Tapagem and Ostras Rivers developed on a gentle surface and flowed into the Ribeira River. With the entrenchment of the Ostras through-valley, the Tapagem River partially infiltrated via a paleosink into the upper passage of the "Erectus Room," remaining a half-blind valley. Following a series of collapses and obstructions, the River next infiltrated via the current sink, creating a fully blind valley. Currently, the cave has a difference in elevation of $120 \mathrm{~m}$ between the sink and the resurgence, which corresponds to the difference in entrenchment between the two valleys.
\end{abstract}

Keywords: $\quad$ marble, through valley, river cave, cave morphology, Tapagem Cave, Brazil

Received ; Revised ; Accepted 10 August 2014

Citation: $\quad$ Filho W.S., Cordeiro B.M. and Karmann I., 2014. Structural and hydrological controls on the development of a river cave in marble (Tapagem Cave - southeastern Brazil). International Journal of Speleology, 44 (1), 75-90. Tampa, FL (USA) ISSN 0392-6672

http://dx.doi.org/10.5038/1827-806X.44.1.7

\section{INTRODUCTION}

Tapagem Cave is one of the most famous and most visited show caves in Brazil and is known for its scenic beauty and the size of its speleothems. It is the $24^{\text {th }}$ longest and the $15^{\text {th }}$ deepest cave in Brazil (out of 5,875 caves, according to the SBE). This cave is situated in the Serra do André Lopes, an isolated body of dolomitic marbles in the Ribeira River Valley in the south of the State of São Paulo in southeastern Brazil (Fig. 1). It is a region with several narrow bands of metamorphic carbonate rocks (mainly metalimestones) of middle to upper Proterozoic age with significant karst systems. There are approximately 400 caves registered in the Ribeira Valley karst terrains. However, caves are rare in the Tapagem Marble, with only 25 caves registered, of which 6 are longer than $100 \mathrm{~m}$ in length and only the Tapagem Cave more than $1 \mathrm{~km}$ in length.

In Brazil, there are approximately 10,000 registered caves, $44 \%$ of which are in carbonate rocks, only $1 \%$ in marble and the remainder in other lithologies (CECAV, 2012).

The geologic and geomorphologic situation of the Tapagem Marble differs from the other karst areas in the region of Ribeira Valley. The Tapagem Marble has a dolomitic composition, which is less soluble than limestones (Rauch \& White, 1970), and it is a marble, a carbonate rock with a low porosity and negligible permeability, making it difficult for karst waters to penetrate (Ford \& Williams, 2007). The dolomitic 


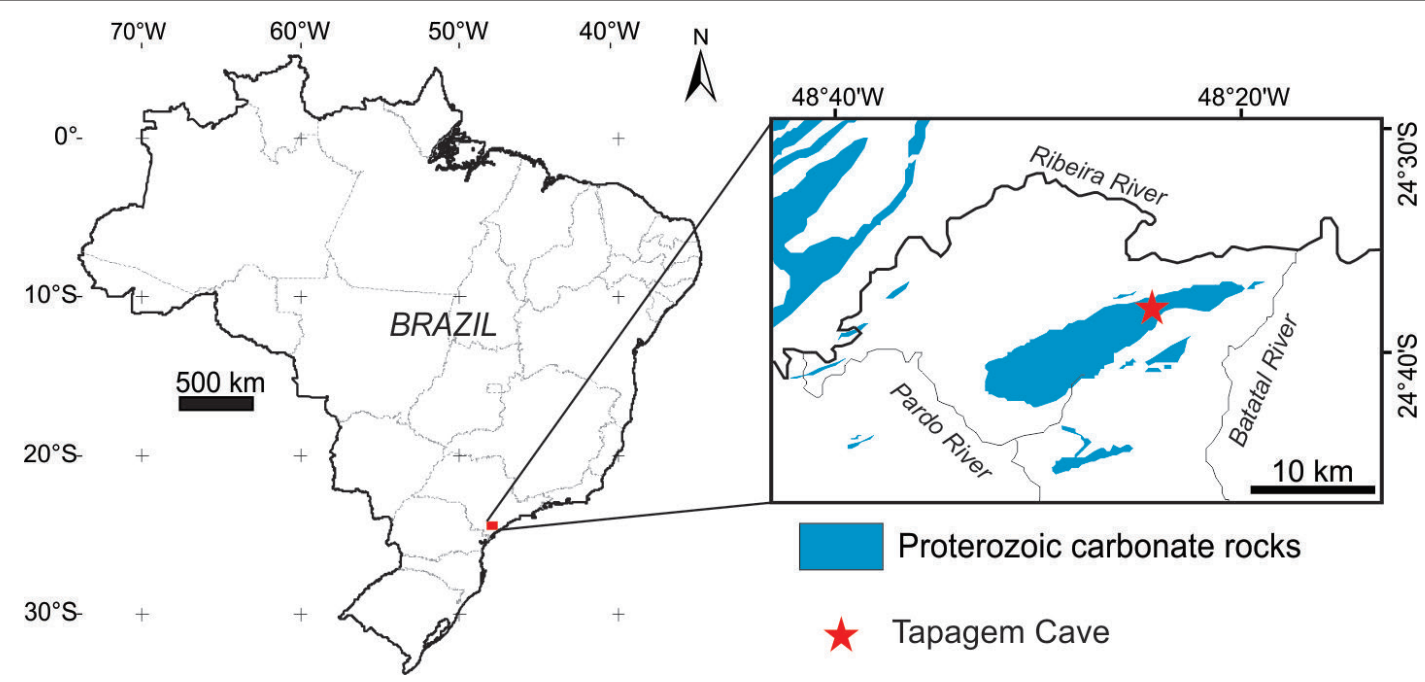

Fig. 1. Map showing the location of Tapagem Cave and carbonate rocks in the southern part of the State of São Paulo and the northern part of the State of Paraná (geology modified after Campanha, 2002).

marble forms a plateau, and mostly of the noncarbonate rocks and metalimestones of the region are at lower elevations.

Typically, narrow bands of carbonate in deformed terrains are favorable for allogenic karstification close to the contact zone (Lauritzen, 2001). The Tapagem Marble consists of a narrow, deformed carbonate band and a plateau, and even with a high perimeter/area ratio and a long allogenic contact zone perimeter, there are only a few points of effective allogenic recharge. The higher portions of the allogenic recharge areas are generally narrow.

Despite the nature of such rocks, there are several examples of cave development in marble (Karmann et al., 2001; Lauritzen, 2001; Despain \& Stock, 2005). Caverna do Ecos (Brazil) has a simple rectilinear conduit morphology, initially developed at the intersections of fractures and bedding planes in the marble and followed by breakdown processes that opened up large vadose rooms in the overlying schist and quartzite. Crystal Cave in the Sierra Nevada (USA) is a complex, multi-level cave composed of six major levels developed in a narrow vertical band of marble (Despain \& Stock, 2005). In Scandinavia, there are good examples of marble caves, such as Larshullet, Storsteinshola, and Horn's No. 1 (Lauritzen, 2001). Lauritzen (2001) considers these caves to be linear systems that drain between two points in the aquifer, preferably from a physical input (sink) to a physical output (spring), guided by geological structures.

In the case of Tapagem Cave, which has been known for more than one hundred years, no detailed geological study had been conducted. As a consequence, the morphology of the cave, the geomorphologic and hydrochemical characteristics of the influence basins, and the geological factors governing the cave were investigated in an attempt to interpret its origin and evolution. This study enabled an understanding of the geological and geomorphological setting of the Tapagem Cave and the processes involved in its evolution; moreover, the study demonstrates the importance of the allogenic waters in marble karst. However, future studies using sediment and speleothem dating will be required to establish the chronology of the events.

\section{REGIONAL SETTING}

The Tapagem Cave, also known as "Caverna do Diabo," or Devil's Cave (commercial name), receives approximately 30,000 visitors/year (Lobo et al., 2013) and is within the Devil's Cave State Park. Tapagem Cave was first described in the literature by Krone (1904) and was the second cave recorded in the state of São Paulo. Krone $(1898,1904,1909)$ was the first to explore the Ribeira Valley region at the end of the $19^{\text {th }}$ Century, recording various caves and emphasizing their scientific relevance and need for conservation. Subsequently, in 1901, Lourenço Granato conducted a survey of land destined to be purchased by the government when the initial exploration and registration of Tapagem Cave occurred, and in 1910, the cave was recognized as a heritage site, remaining under the management of the São Paulo state government since that time (Brandi, 2007).

In 1961, partial exploration was performed by the Centro Excursionista de Itatins (CEI), led by Coronel Petená, who encouraged descriptions of the cave in the press (Zilio, 2003) and was among those responsible for making the cave a growing attraction for tourist activity. In 1967, the cave became known as Devil's Cave for publicity purposes through State of São Paulo Decree No. 48,818. In 1964, Michel Le Bret initiated renewed exploration and mapping of caves in the Ribeira Valley using the information gathered by Krone. The first map was prepared of Tapagem Cave along with the first interpretation of how the cave had formed via unrestricted runoff and rock joints (Le Bret, 1966). Tapagem Cave and its resurgence, Ostras Cave, had been separated due to their inaccessibility, but a route connecting them was discovered by Le Bret in the 1960s (Le Bret, 1975). In addition, in the mid- to late 1960s, the Sociedade Excursionista e Espeleológica (SEE) mapped the cave and conducted biological and meteorological surveys (Matos, 1966; Krüger, 1967). It was only in the 1990s that the Sociedade Brasileira de Espeleologia (SBE), through Project PROCAD, initiated further mapping that resulted in the current plan of the Tapagem cave system (Figueiredo et al., 2007; Rodrigues, 2002). 
The Ribeira Valley karst terrains are found in narrow bands of carbonate rocks (Karmann \& Sanchez, 1986; Fig. 1) lying within the "Ribeira Fold Belt," an orogenic belt of Neo- to Mesoproterozoic age on the east coast of Brazil (Almeida, 1977). Supracrustal rocks of a low to medium degree of metamorphism, known as the Açungui Supergroup, are predominant in this area (Campanha, 1991; Campanha \& Sadowski, 1999).

Tapagem Cave lies in one of these bands, termed the Tapagem Marble, an elliptical body with a major axis of $22.7 \mathrm{~km}$ oriented in a NE-SW direction, and a width of between 1.7 and $5.2 \mathrm{~km}$. It is composed of fine-grained, white, homogeneous metadolomites (Campanha et al., 1985) (Fig. 2) with an apparent thickness of up to $500 \mathrm{~m}$. Along with underlying phyllites, schists and quartzites (Metapelitic Unit), the marble composes the Serra das Andorinhas Sequence (Faleiros et al., 2012), forming a large synformal structure delimited by transcurrent faults (Neoproterozoic-Eopaleozoic) (Campanha, 1991, 2002).

The Tapagem Marble forms the Serra do André Lopes Plateau, a carbonate plateau with narrow rims of phyllites and schists (Serra das Andorinhas Sequence), with an elevation ranging from 330 to 1010 m (Fig. 2).

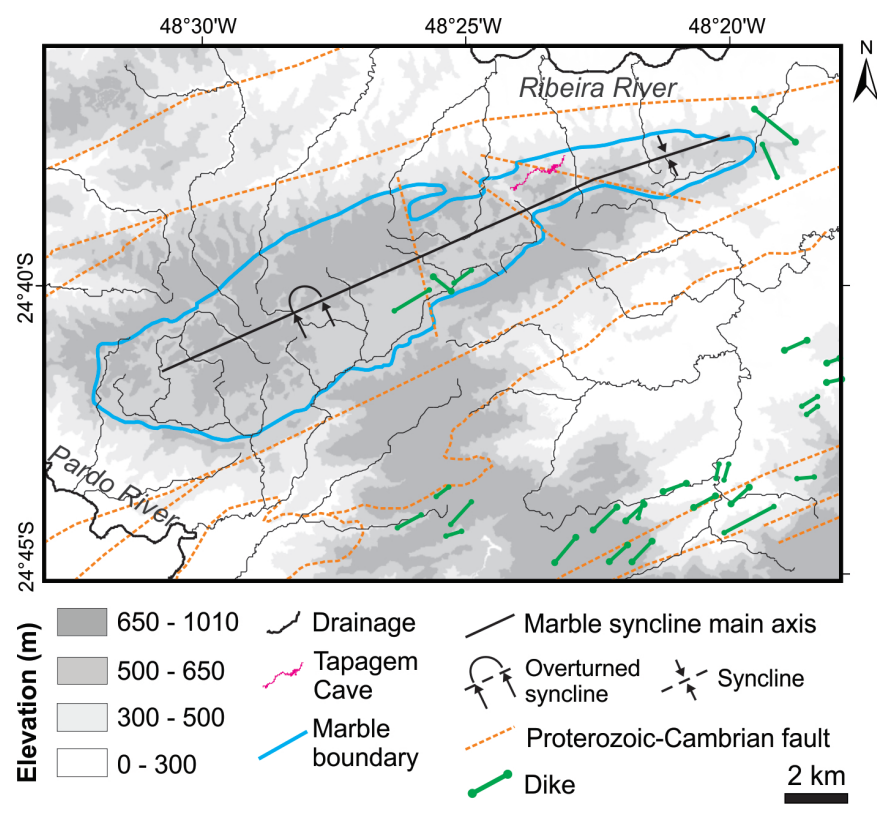

Fig. 2. Geology and hypsometry of Serra do André Lopes and the region (geology modified after Campanha, 2002, and Faleiros et al., 2012, 2013).

The geomorphological evolution of the region is the result of regressive differential erosion and the evolution of the Brazilian continental margin (Almeida, 1964; Almeida \& Carneiro, 1998) related to the origin and evolution of the Serra do Mar range. Mesozoic intrusions occurred in the region during continental fragmentation, forming a NW-SE dyke swarm with a predominance of tholeiitic diabases in the failed arm of a triple junction (Almeida, 1998; Coutinho, 2008) with the injection phase occurring between 131.4 and $129.2 \mathrm{Ma}$, respectively (Renne et al., 1996; Ernesto et al., 1999).

The origin of the Serra do Mar dates from approximately 25 million years after the completion of the continental rifting process (134-114 Ma), when regional uplift was initiated in response to the passage of the South American Plate over the Trindade hotspot (Riccomini, 1995; Zalan \& Oliveira, 2005).It is believed that this uplift ended at the CretaceousPaleocene boundary and gave rise to a regional doming, creating a water divide between the Atlantic Ocean and the continent to the west (Riccomini et al., 2004). The erosional advance of the Ribeira basin into the interior of the continent exposed carbonate rocks of the Açungui Group. Based on a study of karst evolution in the Betari River Valley, Karmann (1994) determined that the entrenchment of the surface in the Upper Ribeira Valley occurred, at a minimum, between the Lower and Middle Miocene.

The region has a humid subtropical climate without a dry season (Alvares et al., 2013), an average annual rainfall of $1600 \mathrm{~mm}$ and an average annual temperature of $18^{\circ} \mathrm{C}$, with a dense Atlantic Rainforest. The base level of erosion in the Serra do André Lopes is the channels of the Pardo and Ribeira rivers, which in this sector are at altitudes of 30 to $150 \mathrm{~m}$ (Fig. 2). Significant deposition of tufas occurs along the local drainage channels due to the essentially autogenic nature of their recharge waters (Sallun Filho et al., 2012).

\section{MATERIALS AND METHODS}

Geomorphological mapping was performed on the surface, demarcating the karst features and the drainage network using a stereoscope and panchromatic aerial photographs on a scale of 1:25,000; contours were generated using Shuttle Radar Topographic Mission (SRTM) and field survey data until the final mapping was obtained and united in an ARCGIS 10 (ESRI) environment. Topographic cross-sections of the surface relief and longitudinal profiles of the river were prepared from the SRTM base data using Global Mapper 15 (Blue Marble Geographics) software to gain a better understanding of the setting of the cave relative to the plateau and the hydrographic basins. The longitudinal profile of the river was constructed from its source to its mouth. The hydraulic gradient was calculated based on this profile, using the difference in elevation divided by the horizontal distance.

The autogenic and allogenic recharge areas were calculated based on the area of all of the drainage basins over the marble and the non-carbonate rocks, respectively, using a 1:100,000 geological map from Faleiros et al. (2012, 2013).

The $\mathrm{pH}$ and temperature were measured using a multiparameter instrument (Hanna HI 98129). For the saturation index (SI), two water samples recovered during the rainy (summer) and dry (winter) seasons were collected from two sites (the Tapagem and Ostras Rivers). The SI calculation was based on the Langmuir (1971) equation and was processed using AquaChem 5.1 software.

The marble structure was delineated from structural data taken during hikes on the surface, resulting in geological cross-sections. A lithologic analysis in the cave was performed using thin sections of the marble and diabase dykes, and chemical analyses using $\mathrm{X}$-ray fluorescence were performed on two samples of marbles to determine the major element contents (presented as \% of oxides). The oxides was converted 
into quantities of dolomite, calcite and impurities, as determined by Martinet \& Sougy (1961), and classified according to Leighton and Pendexter (1962). The sample collection in the cave was performed in accordance with Brazilian legislation and authorized by CECAV-ICMBIO (No. 30591-1). For structural geology, the fractures, banding and dykes were measured in the cave and on the surface, and then merged in stereograms, plan views and cross-sections.

The study of the morphology of the cave was based on previously topographic mapping performed by PROCAD (Devil's Cave Project - SBE, 2008) and several surveys of Tapagem Cave. During the surveys, thirty transverse cross-sections and one longitudinal crosssection were generated using a laser distance meter to measure the width and height of the passages.he altimetric elevation of the initial topographic base of the cave of $460 \mathrm{~m}$ at the sink was based on GPS location on the 1:10,000 topographic base map (IGC, 1988). From the sink, it was possible to establish a correspondence between relative elevations derived from cave mapping and altimetric elevations used in the sections and cave levels. The morphometry of the cave is based on the cave map. The cave river gradient was calculated using the elevation (the difference in elevation divided by the horizontal distance) and slope (measuring of the inclination in degrees of the longitudinal profile of the river). The sinuosity index of the river cave is the ratio of the length measured between two points along the river to the straight line between two points.

The transverse cross-sections and photographs of the cave are displayed in the sink-to-resurgence direction.

\section{RESULTS}

\section{Ostras - Tapagem Basin}

The Tapagem cave has developed from the Tapagem River sink at an elevation of $460 \mathrm{~m}$ asl, with the Ostras River as its discharge area (resurgence) at $340 \mathrm{~m}$ asl (Fig. 3A). The Ostras and Tapagem River valleys lie nearly parallel to one another in a NW-SE direction and are the basins that receive most of the allogenic recharge and have the largest area of non-carbonate rocks in the Tapagem Marble karst (Fig. 3A, 4). Other large areas of non-carbonate rocks have rivers that flow to points outside the karst (Fig. 2).

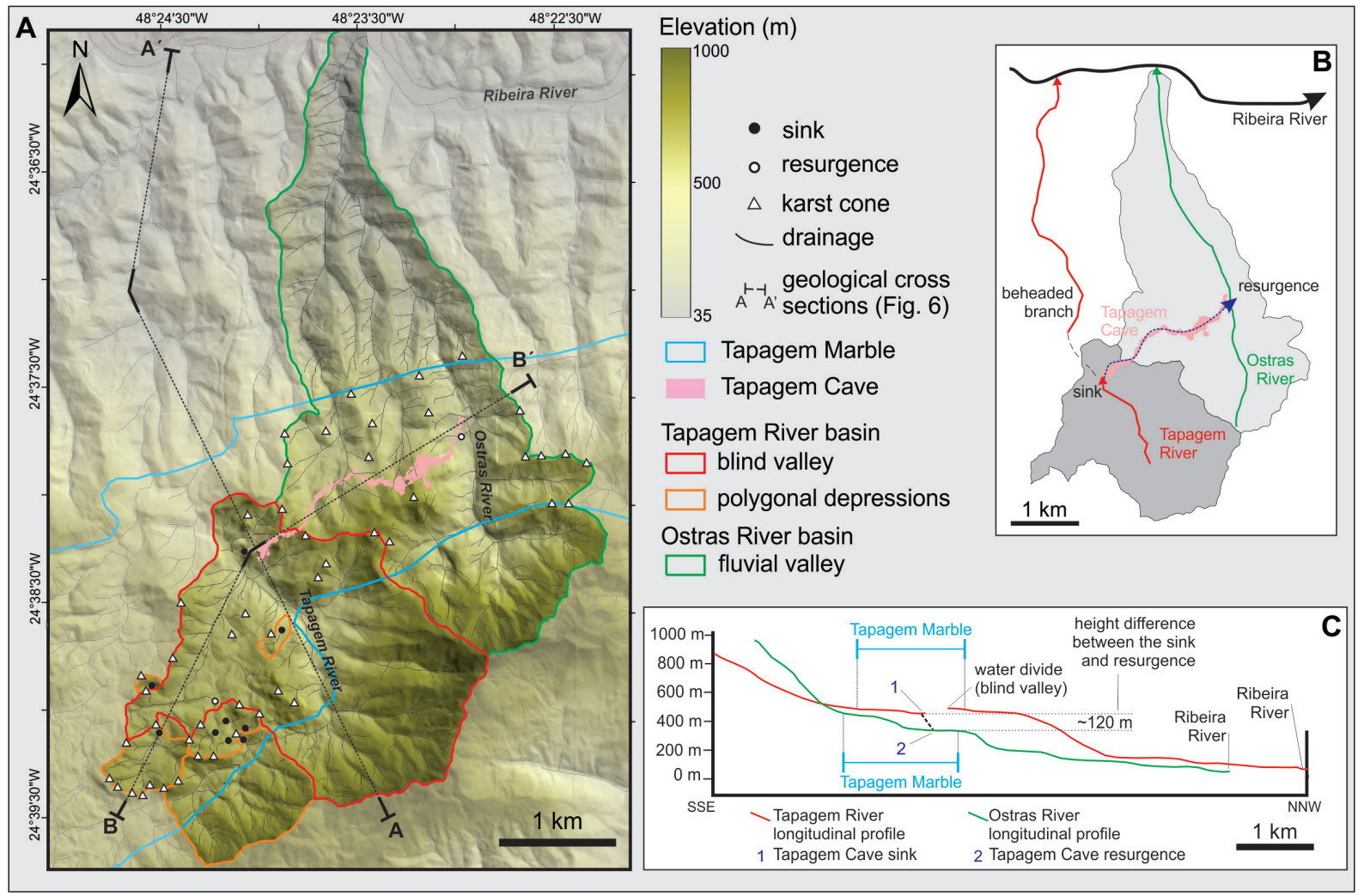

Fig. 3. The Ostras - Tapagem basin. A) DEM of the Tapagem River basin with the location of the marble and karst features and projection of Tapagem Cave; B) Diagrammatic drawing of the Tapagem River catchment area; C) Longitudinal profile of the Tapagem and Ostras rivers.

The Tapagem Valley is in the narrowest portion of the entire band of marble, with allogenic recharge from elevated borders to the southeast (600 to $924 \mathrm{~m}$ ) composed of weathered phyllites and micaschists. The overall hydraulic gradient is 0.157 , ranging from 0.3 at its headwaters to 0.068 in the marble down to the sink.

In its upper-middle course $(580 \mathrm{~m})$, the river flows in a narrow channel in a deeply entrenched valley at the contact between the metapelites and marbles. In the marble, the valley becomes more open with an extensive alluvial plain (488 $\mathrm{m}$ asl) and, about $700 \mathrm{~m}$ from the contact, makes an abrupt change to the NE to enter the cave sink (blind valley). At a distance of $450 \mathrm{~m} \mathrm{NW}$ of this abrupt change in direction there is a smooth topographic divide $16 \mathrm{~m}$ higher in elevation that separates the blind valley from the remainder of the Tapagem River Valley, providing evidence of its former continuation to the Ribeira River.

The Tapagem River basin is now a blind valley with surface runoff discharged into Tapagem Cave and the Ostras River as the local base level $120 \mathrm{~m}$ below it (Fig. 3B, C). The underground route followed by Tapagem 


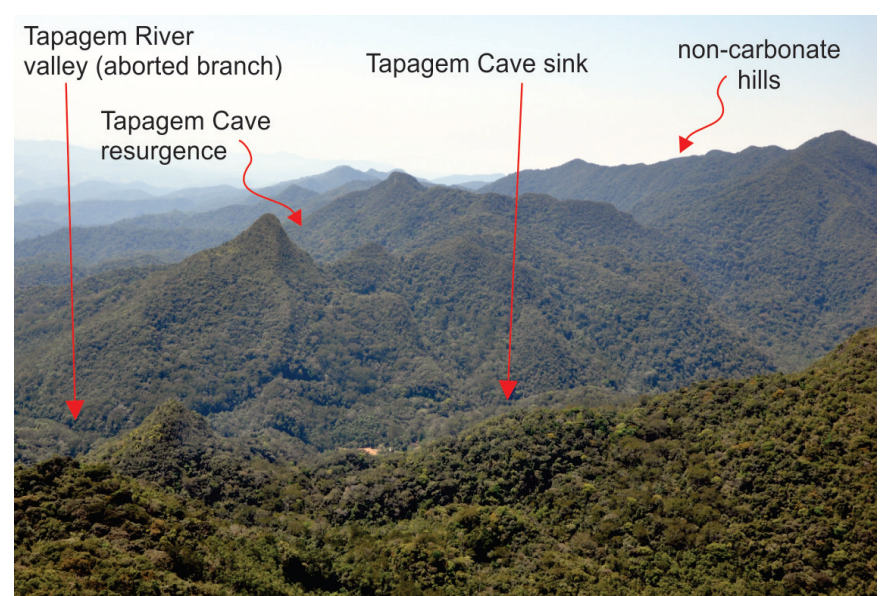

Fig. 4. Oblique aerial photograph of the Tapagem River Valley, the ridge over the cave and the Ostras River Valley in the background (view to the NE).

Cave developed perpendicular to the trend of the surface runoff (Fig. 3A, B). The blind valley captures all of the water at the Cave sink, a surface catchment basin of approximately $6 \mathrm{~km}^{2}$ with an autogenic recharge area of $3.7 \mathrm{~km}^{2}(61.72 \%)$ and allogenic recharge of $2.3 \mathrm{~km}^{2}$ (38.28\%) forming a mixed system.

Although the Tapagem and Ostras rivers have high $\mathrm{pH}$ values $(8.31$ and 8.63 in the summer and 8.37 and 8.53 in the winter, respectively), the saturation index for calcite is low in the Tapagem River $(+0.11$ in the summer and +0.38 in the winter) and high in the Ostras River $(+0.67$ in the summer and +0.73 in the winter), indicating less saturated waters with a certain amount of dissolution capacity at the sink, especially during the rainy season (summer).

The Ostras River cuts deeper into the rock and reaches lower elevations in the marbles (Fig. 3C); the mean channel gradient is 0.163 , ranging from 0.5 in the up-gradient phyllites to 0.095 in the marbles and 0.084 in the down-gradient phyllites.

\section{Lithology and structural geology}

The most prominent feature of the marble structure is the compositional banding (Fig. 5A). The initiation of the cave is likely related to the intersection of this banding with axial plane cleavage, as observed in certain protoconduits (Fig. 5A). The banding consists of $\mathrm{S}_{1}$ foliation, a relic of $\mathrm{S}_{0}$, folded in the form of recumbent, isoclinal intrafolial folds. Microscopically, it is possible to observe a granoblastic texture and fine granulation oriented in accord with $\mathrm{S}_{1}$ (Fig. 5B, C). Chemically, the marble can be classified as dolomite and calcareous dolomite (dolomite: 98.44 and $90.16 \%$; calcite: 0.00 and $12.25 \%$; impurities: 1.85 to $0.00 \%$ ) with little or no impurity (terrigenous sediments).

On a larger scale, the Tapagem Marble is in a syncline with smaller secondary folds, forming the complex folding patterns typical of marbles. Tapagem Cave is located on the NW flank of the principal syncline (Fig. 6) and, more specifically, on a secondary anticline with a 246/35 axis (Fig. 6, 7). Marble banding in the cave is oriented $\mathrm{NE}-\mathrm{SW}$, with dip angles of $65^{\circ}$ and $90^{\circ}$ to the NW in

Fig. 5. A) Protoconduit in the river passage controlled by marble banding / cleavage with high dip angles to the NW (left); B), C). Photomicrograph of the dolomitic marble with a granoblastic texture and fine granulation (uncrossed polarizers - B, and crossed polarizers - C).
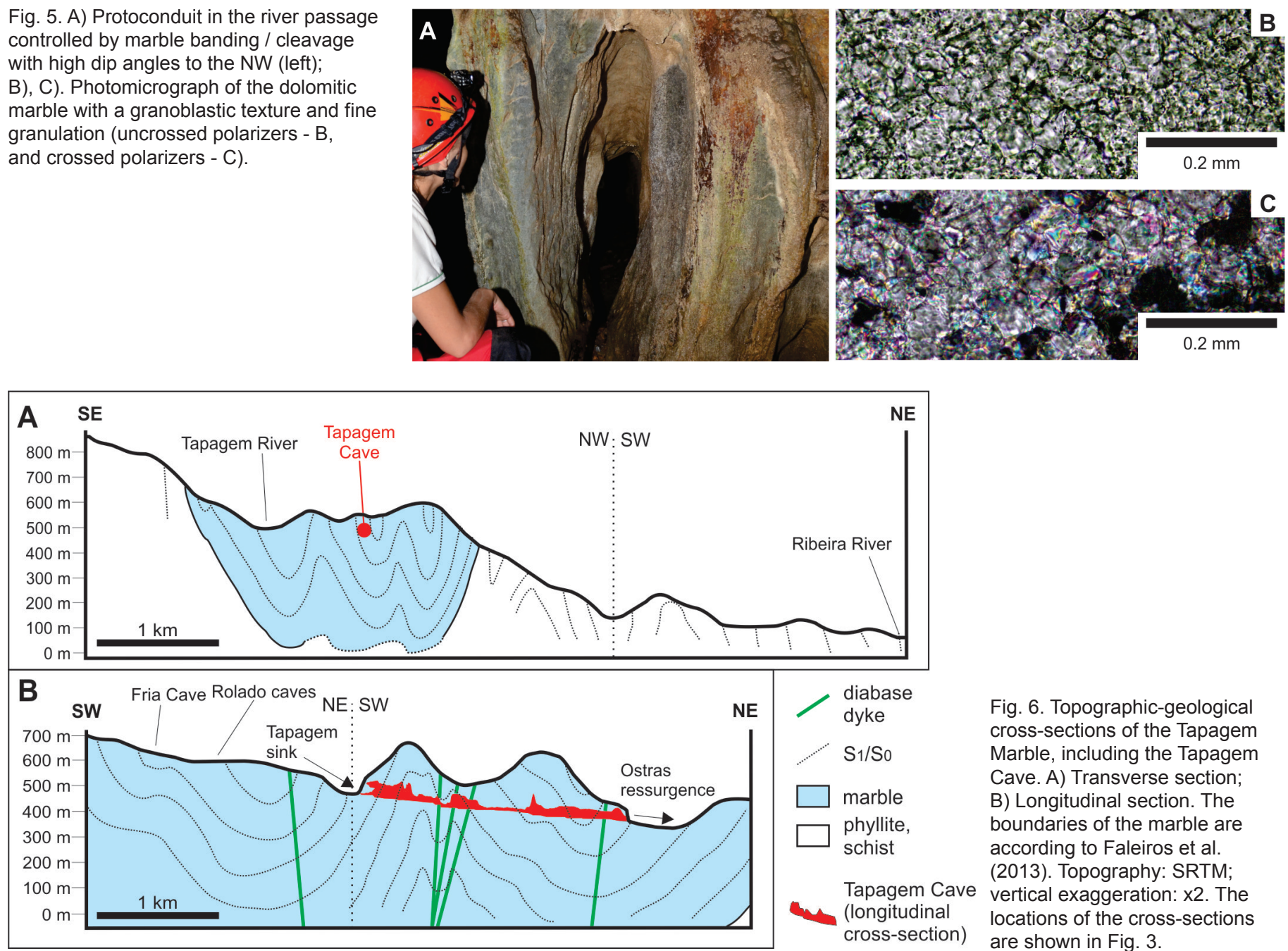

Fig. 6. Topographic-geological cross-sections of the Tapagem Marble, including the Tapagem Cave. A) Transverse section; B) Longitudinal section. The boundaries of the marble are according to Faleiros et al. (2013). Topography: SRTM; vertical exaggeration: $x 2$. The locations of the cross-sections are shown in Fig. 3. 
certain places and to the SE in others characterizing the anticline (Fig. 6-8).

Four diabase dykes were identified in the cave (dykes 1 to 4; Fig. 8A, B; Table 1) perpendicular to the overall orientation of the marble banding, with a NW-SE orientation, a dip to the SW (Fig. 7) and widths between 0.4 and $3.0 \mathrm{~m}$ (Fig. 9A, B). The dykes are massive tholeiitic basalts of fine granulation and a glomeroporphyritic texture. The dykes have cooling fractures; only dyke 4 has columnar joints perpendicular to the walls. Because they are less soluble rocks, the dykes stand out from the marbles on the cave walls (Fig. 8) and determine the sectors with a higher river gradient (Fig. 8C, D).

Dykes have not played a part in controlling the evolution of the cave, although certain conduits developed along the plane of the associated NW-SE fracturing. These fractures cause abrupt changes in the NE-SW pattern of the river passage and stretches of higher sinuosity index (Fig. 8E), and they control the maze sectors of the cave (Fig. 8A).

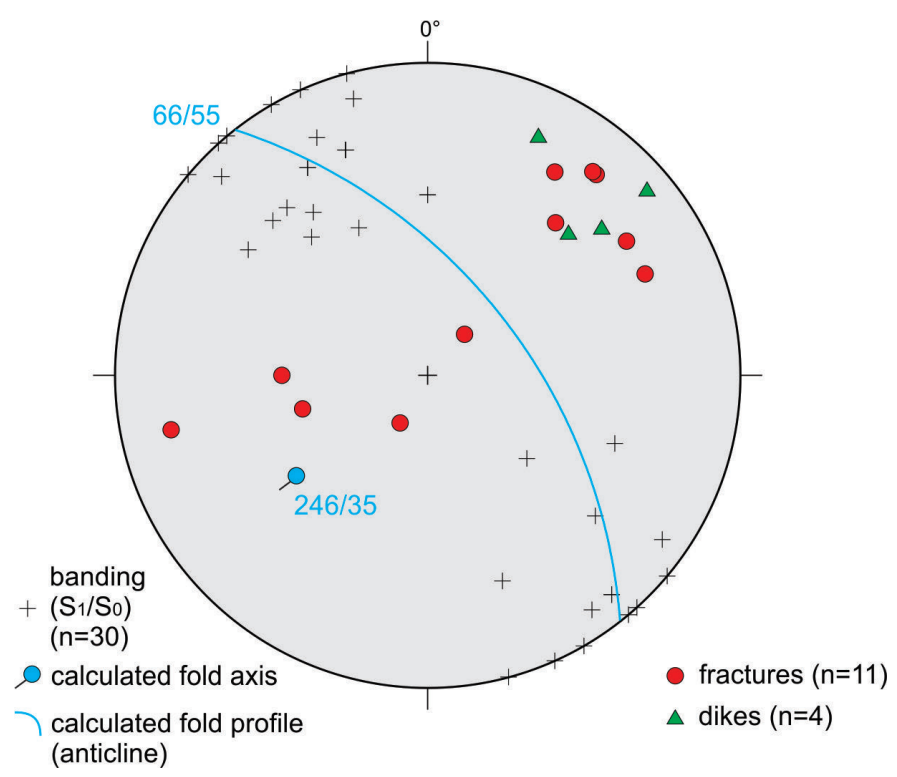

Fig. 7. Stereogram from Tapagem Cave showing the poles of the planes of the marble banding, dykes and fractures and the great circle of the fold profile and the pole of the calculated fold axis.

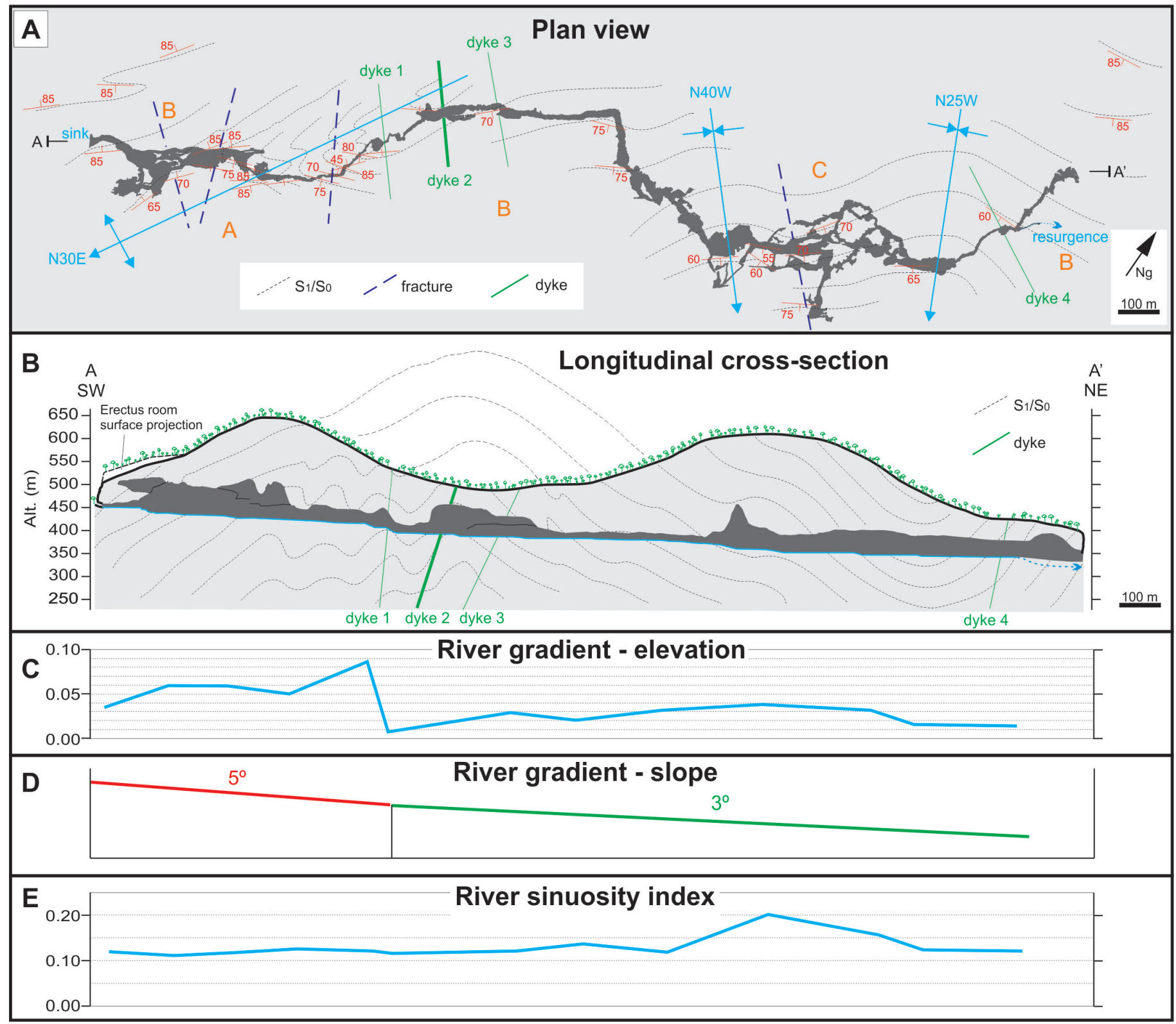

Fig. 8. Structural and morphological features of Tapagem Cave. A) Plan view of the cave with the geological structures and morphological sectors;

B) Longitudinal section (projected) with the geological structuresl; C) River gradient (based on elevation); D) River gradient (slope);

E) Sinuosity index of the river. 
Table 1. Characteristics of the diabase dykes found in Tapagem Cave.

\begin{tabular}{|l|l|l|l|}
\hline & Strike & Dip & Thickness (m) \\
\hline Dyke 1 & N40W & 85SW & 0.8 \\
\hline Dyke 2 & N40W & 72SW & 3.0 \\
\hline Dyke 3 & N45W & 65SW & 0.45 \\
\hline Dyke 4 & N65W & 80SW & 0.4 \\
\hline
\end{tabular}

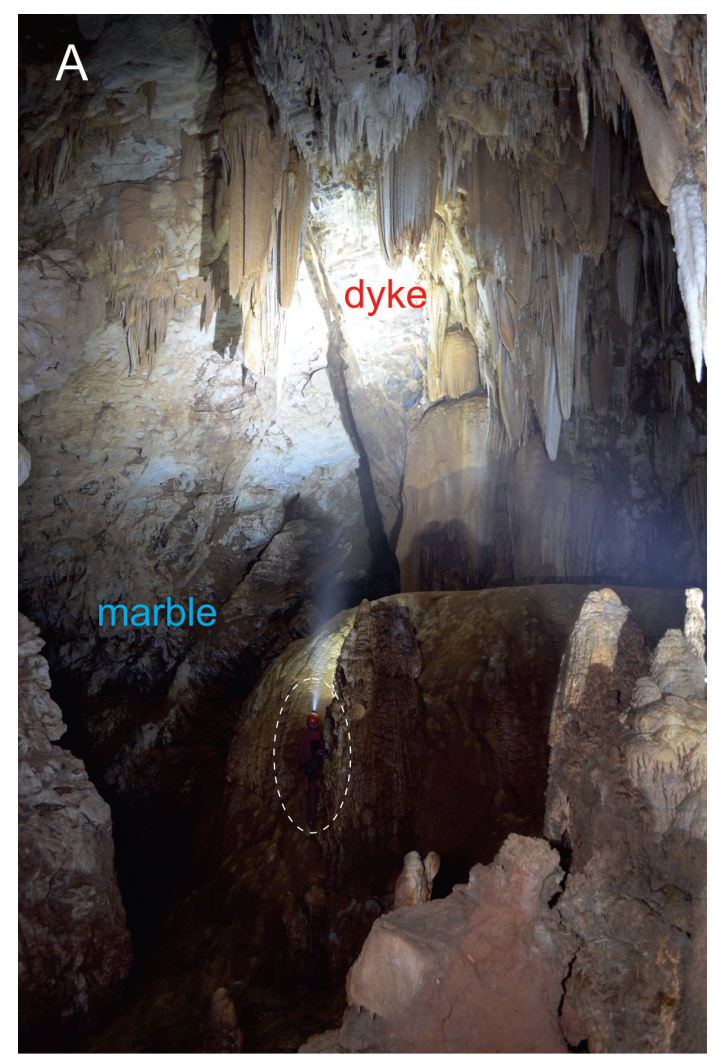

\section{Morphology}

The cave developed over a horizontal distance of approximately $6,237 \mathrm{~m}$, with a total difference in elevation of $175 \mathrm{~m}$ and of $120 \mathrm{~m}$ between the sink point and the resurgence (SBE, 2008). On the surface, there are ridges, valleys and hills (Fig. 4) resulting in a bedrock thickness over the cave that ranges from 32 to $240 \mathrm{~m}$ (average of $103 \mathrm{~m}$ ).

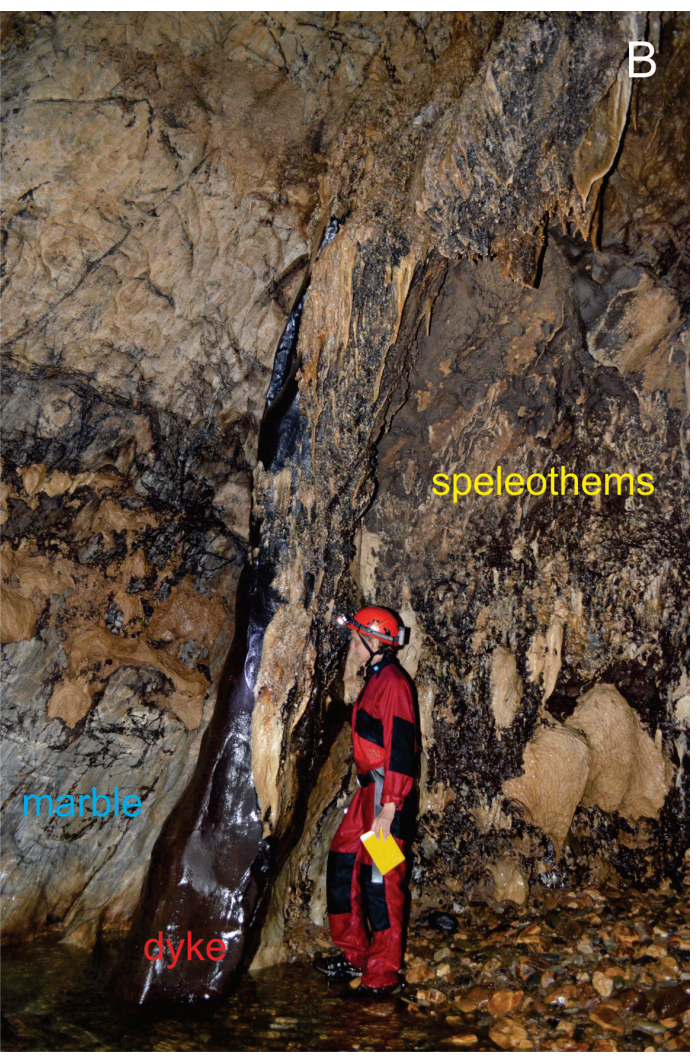

Fig. 9. Diabase dykes encountered in Tapagem Cave. A) Dyke 2; B) Dyke 4.

In plan view, the cave's morphology is predominantly that of an active river cave that has developed in a sinuous manner (Fig. 8). In its cross-section form, the principal passage is generally an underground canyon with upper passages that are occasionally interrupted by large collapse rooms. The plan view morphology of the cave is principally controlled by the NE-SW compositional banding and cleavage and, locally, by the NW-SE fractures (Fig. 8). According to its morphological characteristics in plan view and cross-sections, it was possible to identify distinct sectors of the cave with different morphology and structural controls.

\section{The Tourist Sector and Gava Passage (A)}

This portion begins below the sink and is the initial segment of the cave, with extensive intermediate and upper rooms and passages. The passages and rooms develop in a NE-SW direction and are vertical or inclined to the NW in accordance with the marble banding in the northwest flank of the anticline (Fig. 7, 8).

The Tourist Sector is at an intermediate level and is composed of large rooms in which concrete gangways and stairs have been installed for visiting tourists along a route of approximately $800 \mathrm{~m}$ (Fig. 10A).

The morphology of the "Tourist Sector" consists of smooth walls inclined in accordance with the banding of the marble and altered by collapse processes (Fig. 11-2).
The richness, size, and beauty of the speleothems in this sector are noteworthy and make Tapagem Cave the tourist cave of greatest scenic beauty in the state of São Paulo, and one of the most remarkable in Brazil. Columns with a height of more than $20 \mathrm{~m}$ and a diameter of $6 \mathrm{~m}$ and stalagmites with heights more than $15 \mathrm{~m}$ are deposited upon an immense pile of collapsed blocks of rocks and earlier speleothems. Various fallen speleothems show the growth of new flowstones, stalagmites and columns, which are also of a large size (Fig. 10B). A large colluvial-eluvial deposit with blocks of the marble with large stalagmites upon them, the "Cathedral Room," fills a portion of one of the rooms (Fig. 10C, 11-2). This sediment was injected by a vadose invasion originating from a collapse depression (doline) above the cave.

The "Erectus Room" is the highest in the cave, at a level 50-60 $\mathrm{m}$ above the current river (Fig. 11-1). This room is highly decorated by various types of speleothems, especially stalagmites and fluvial deposits with the associated allochthonous material. The direction of the passage and its elliptical shape in cross-section are controlled by the dip of banding. The location and orientation of this passage, as a branch of the principal passage, suggests that it was the paleosink of the Tapagem River. 
The "Rede Gava" is an upper level of the current river canyon that is partially isolated from it by speleothems and sediment levels (Fig. 11-3, 11-4). The difference in elevation between the "Rede Gava" and the current water level is up to $50 \mathrm{~m}$. The crosssections are elongated, following the vertical structure of the banding in the rock, and are remnants of the river passage canyon.
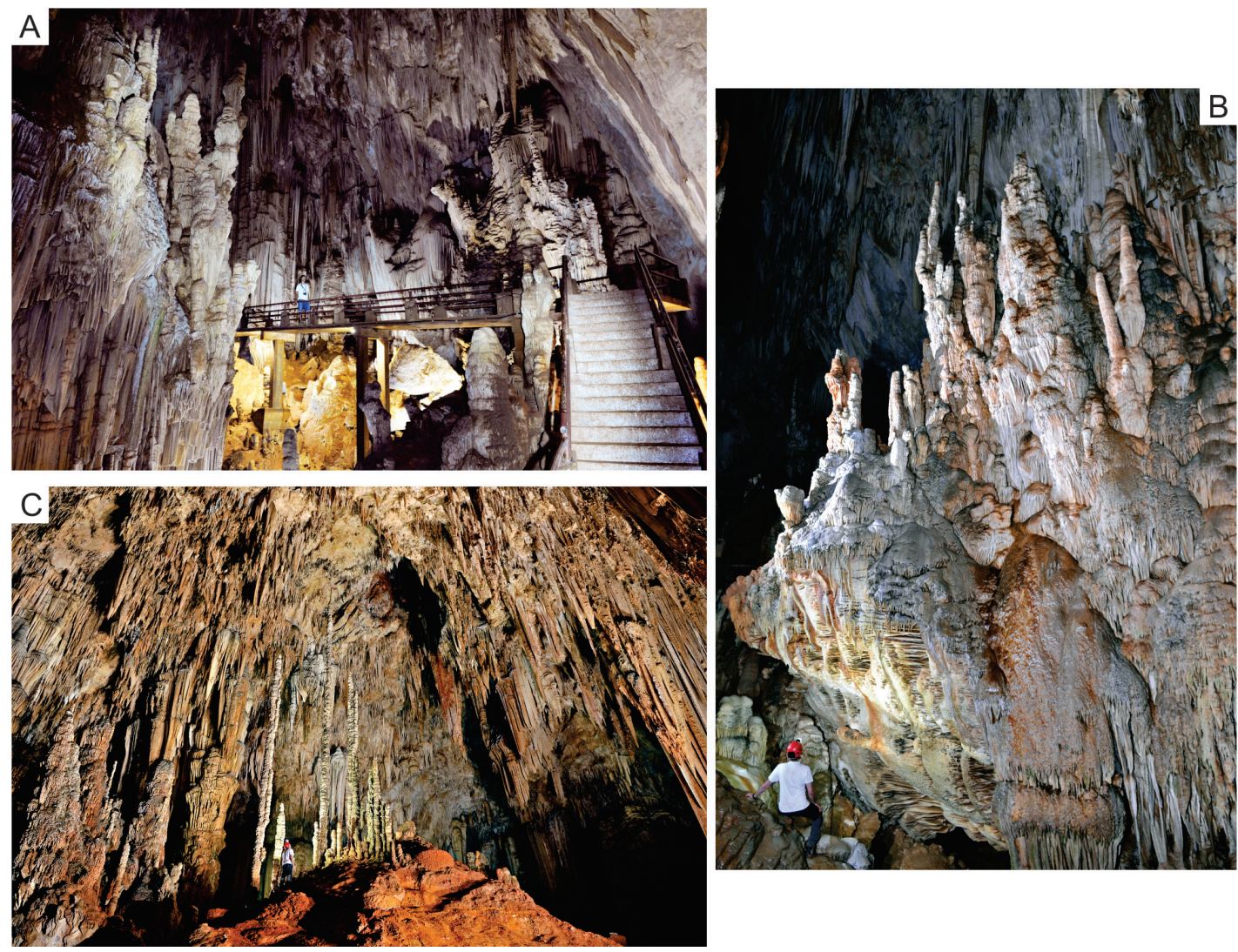

Fig. 10. Tourist Sector. A) Room formed by collapse events and filled with speleothems; B) Large fallen stalagmite with the subsequent growth of other stalagmites upon it; C) "Cathedral Room" with a cone of colluvial-eluvial sediment injected from the surface and the subsequent growth of large stalagmites (Photos: Adriano Gambarini).

\section{River Passage (B)}

The river passage begins shortly after the cave sink (460 $\mathrm{m}$ asl) and continues in a sinuous manner although it is entrenched into the left side (NW) of the passage. In plan view, the passage is narrow, elongated (2.84 $\mathrm{km}$ in length) and sinuous (sinuosity index of 1.3).

Most of the river passage has the form of an underground canyon, with certain sections showing more circular shape and rooms with a concave ceiling and collapse blocks on the ground. Generally, the canyons show rectilinear, vertical or inclined walls (Fig. 12) with their direction alternating with the dip direction in accordance with the attitude of the marble structure; however, in certain cases, the dip direction is in accordance with the hydraulic gradient rather than the structural features. The width of the canyon ranges from 2 to $15 \mathrm{~m}$, in proportion to the height of the passage which varies from 20 to $70 \mathrm{~m}$ throughout the cave (Fig. 12). In the sectors in which the passage has been partially filled by speleothems or the ceiling is inaccessible, it is difficult to visualize and interpret its original morphology.

In the first half of the cave, the river passage trends NE-SW, with a cross-section that is vertical or inclined to the NW following the banding in the marble (Fig. 12-5) in the NW part of the anticline (Fig. 7, 8). In the other half of the cave, the passage still follows the NESW banding but is inclined to the SE following the dip of the banding in this direction (Fig. 12-8) in the SE part of the anticline (Fig. 7,8 ).

In the central portion of the cave, there is a 90-degree change in the direction of the passage where the cave follows a $\mathrm{NE}$ direction before continuing to the $\mathrm{SE}$ perpendicular to the bedding. At this point there is fracture or fault control related to the dykes, and the dip of the banding changes direction from NW to SE. In cross-section the passage morphology becomes circular to elliptic, as in the case of phreatic features.

Several smaller collapse rooms interrupt the river passage canyons. A large room opens up that is influenced by dyke 1 ("Dyke Room"), with a collapse of the marble and dyke rock (Fig. 9A). In the sector near dykes 1, 2 and 3, the river has more waterfalls (i.e., a higher gradient; Fig. 8C).

Slightly more than $200 \mathrm{~m}$ from the cave exit (which is a fossil resurgence), the channel enters a siphon descending approximately $60 \mathrm{~m}$ beneath the water table before its resurgence between rock blocks in the Ostras River valley at an elevation of $340 \mathrm{~m}$.

Generally, the underground river is flowing over deposits of pebble- to boulder-sized clasts of marble, phyllite, quartzite, quartz and diabase (rounded or columnar joints) along with speleothems, originating from the collapse of the upper passages. Less often, there are deposits of sand or mud or the stream flows on bedrock where erosive features of the pothole type are very common in the riverbed. 


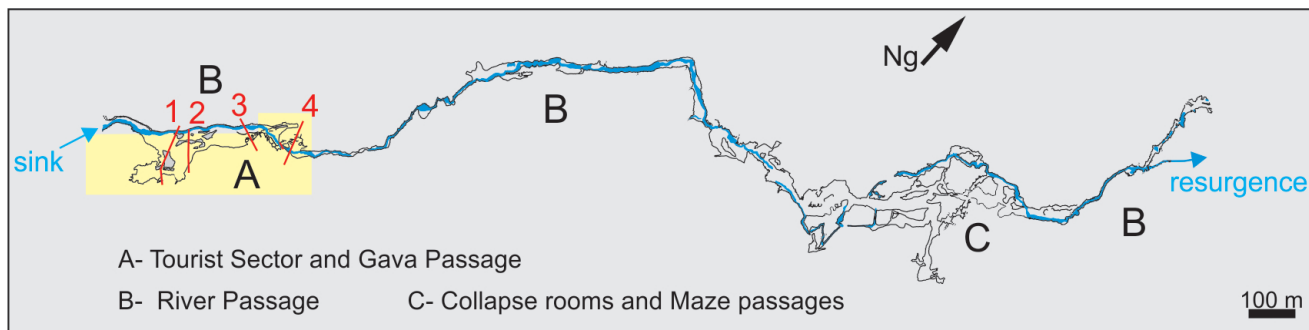

$50 \mathrm{~m}$
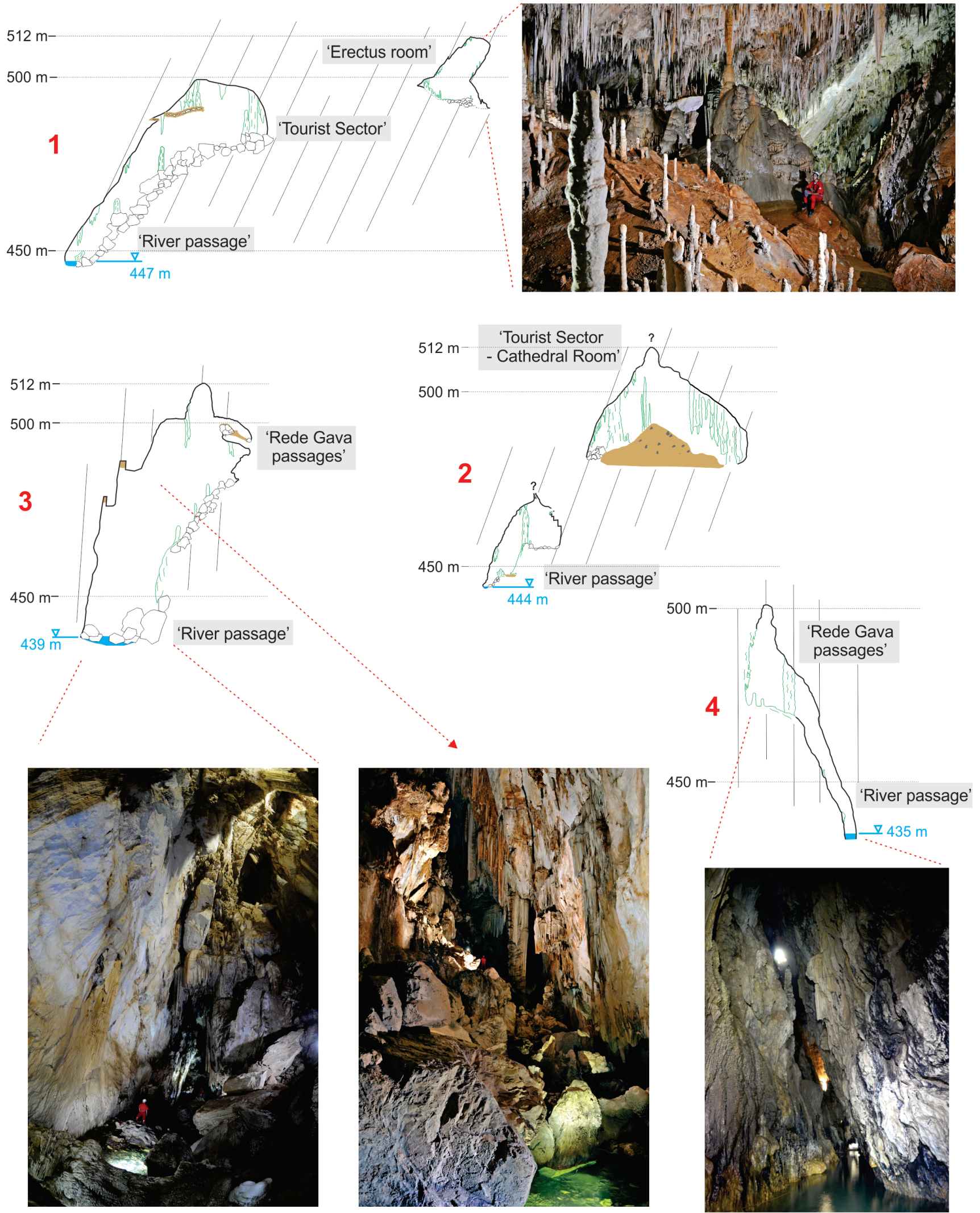

Fig. 11. Cross-sections of Sector A. 1) Morphology controlled by the banding in the river passage and the upper room of the "Erectus Room"; 2) Morphology controlled by the banding in the river passage and the intermediate level of the "Tourist Sector"; 3) Canyon controlled by the banding and the upper level of the "Rede Gava" (second photo looking toward the sink); 4) Vertical canyon and the upper level of the "Rede Gava" (Photos 1, 2, 3: Adriano Gambarini). 

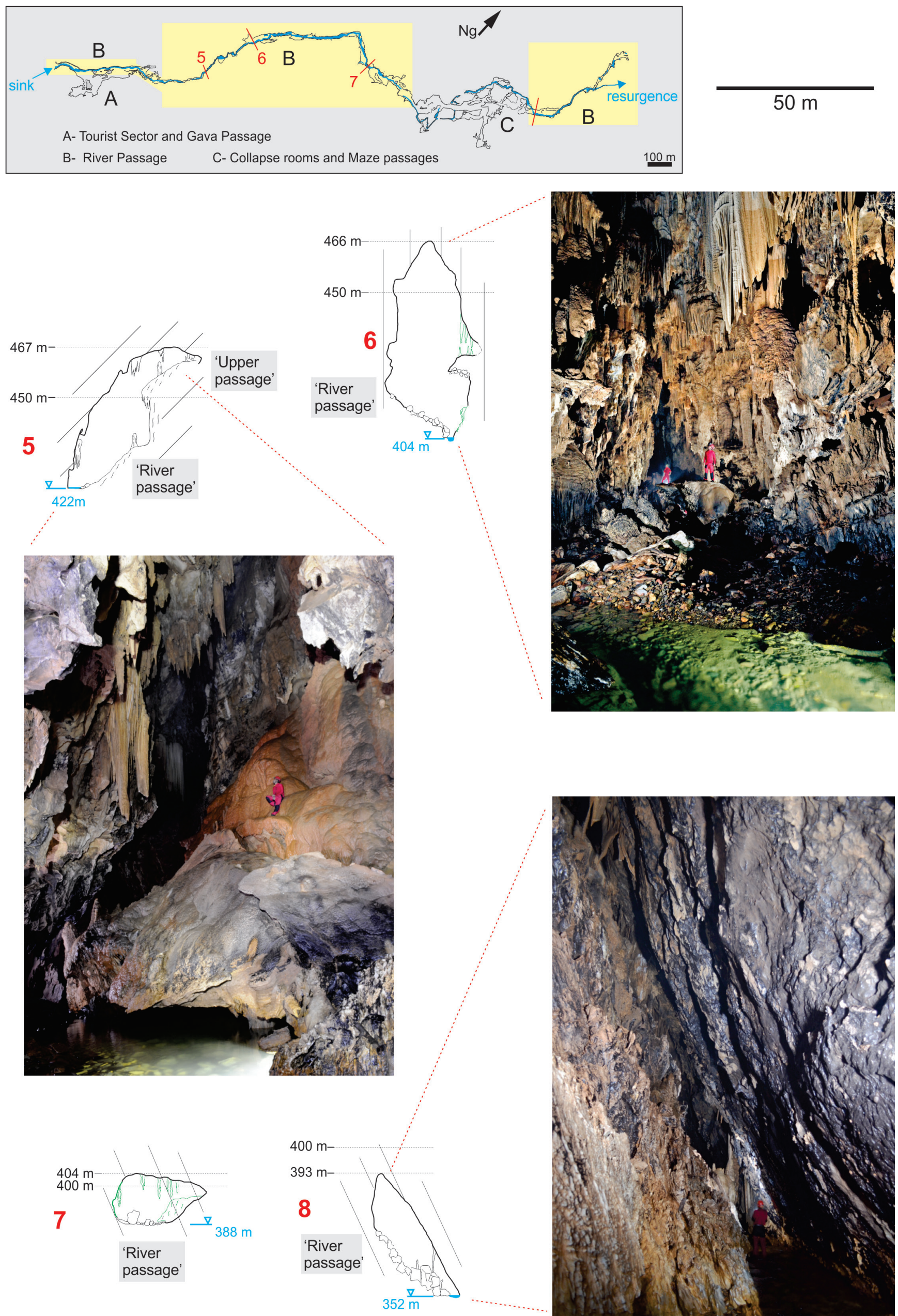

Fig. 12. Cross-sections of Sector B. 5) Canyon and upper passages; 6) Vertical canyon; 7) Elliptical morphology; 8) Canyon inclined to the SE (Photos 5, 6: Adriano Gambarini). 
Collapse Rooms and Maze Passages (C)

Section C differs from the other sections in that a series of rooms and abandoned stream passages interrupt the homogeneous sinuous pattern of the modern river passage. These passages are oriented in NE-SW and NW-SE directions, accordant with banding in the marble in the SE flank of the anticline and fracturing associated with the dykes. The predominant morphology of the large rooms is that of bedrock collapse, as in the "Fallen Giants Room," the "White Room" the "Philippe Room," and particularly the "Michel Room" which has a height of 80 m (Fig. 13-9).

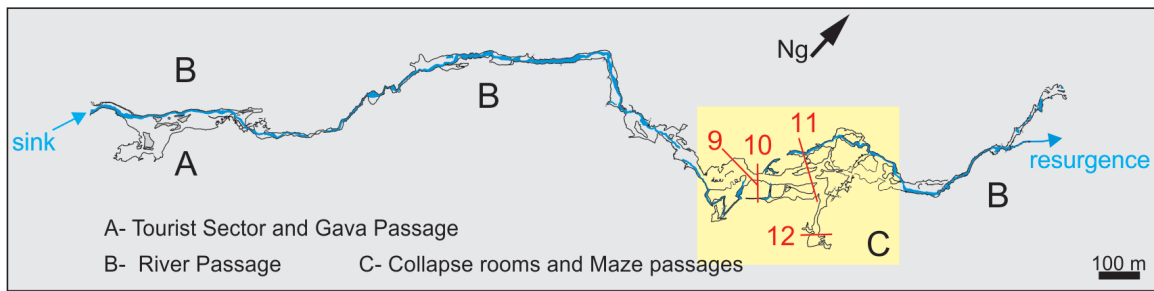

$50 \mathrm{~m}$

B- River Passage C- Collapse rooms and Maze passages $00 \mathrm{~m}$
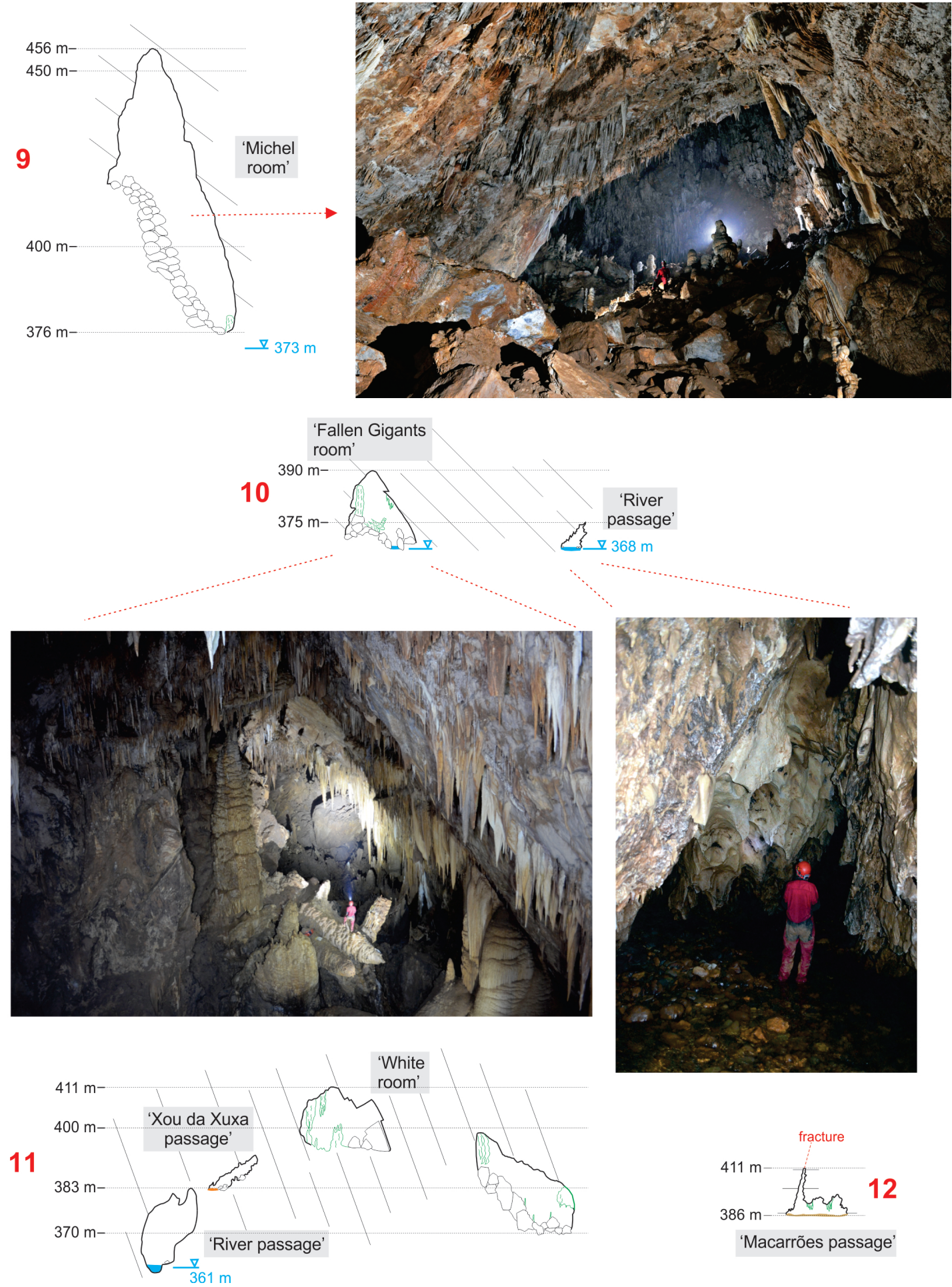

Fig. 13. Cross-sections of Sector C. 9) Large collapse room (the "Michel Room," 80 m high; photo looking upward); 10) Collapse room with fallen stalagmites (the "Fallen Giants Room") and the "River Passage"; 11) Four passages, the upper "White Room" and diversions to the SE and NW (the "Xou da Xuxa" and "River Passages"); 12) The Macarrões Passage (Photos 9, 10: Adriano Gambarini). 
These passages are located at various levels (Fig. 13-11) that are masked by collapse events, forming several rooms and comprising a complex network that, in plan view, is a maze. The "Philippe Room", up to $10 \mathrm{~m}$ above the current river, is connected to the river passage (B) by the downgradient "Barro Passage". The original morphology of the "Xou da Xuxa" (NE-SW) and "Macarrões Avenue" (NW-SE) passages remains well preserved, the former corresponding to an entrenchment and the latter showing phreatic features, both forming a second level $20 \mathrm{~m}$ above the current river. The morphology of the phreatic passage in the "Macarrões Avenue" passage is interpreted as a fracture-controlled phreatic initiation succeeded by bedding-controlled vadose widening. The central passage extends from the "Fallen Giants Room" and the "White Room," which is connected to the "Black Room" via the "Alto do T." This is the highest level in Sector C, $40 \mathrm{~m}$ above the river.

The rooms have irregular ceilings, and floors filled with large fallen blocks that obstruct the river, making its progress difficult and forcing it to penetrate between the blocks and abandon its principal course for routes at lower elevations. There are large fallen speleothems, including two stalagmites known as the "Fallen Giants" (Fig. 13-10). In cross-section, the river channel morphology becomes triangular passages of smaller dimensions than the underground canyon elsewhere.

After the change in direction of the river, the channel adopts a highly structured form (Fig. 8). At this point, passages trending SE diverge (braid) in various directions, determined by the foliation in some places and by the NW-SE fractures in others. Considering the route followed by the river alone, its sinuosity index is higher in Sector C, between 1.5 and 2.0 (Fig. 8E).

\section{Cave levels}

By observing elements that record the phases in the fluvial entrenchment and depositional processes, four levels of evolution of the cavity were identified, which were parallel to the overall trend of the cave and river. Palmer (1987) has proposed that cave levels (passages) are controlled by a fluvial base level which, in the case of Tapagem Cave, is the through valley of the Ostras River.

The $1^{\text {st }}$ level corresponds to the course of the current river, which begins at the Tapagem River sink and extends up to $10 \mathrm{~m}$ above the river. The $2^{\text {nd }}$ level is found at 10 to $20 \mathrm{~m}$ above the $1^{\text {st }}$ level, characterized by erosional features such as the undermining of the base of speleothems, light sediment deposition and fluvial terraces along the river passage. In the Tourist Sector near the sink, it is possible to clearly observe its record on the walls of the passage and through the light sediments. The $3^{\text {rd }}$ level is found at a height of 30 to $40 \mathrm{~m}$ above the river, with fluvial terraces being encountered in the Tourist Sector and the "Rede Gava", sediments cemented in the form of pendants that indicate this level of erosion and by the "Macarrões Avenue" at this level in Sector C. The $4^{\text {th }}$ level, the highest, is found at a height of more than $40 \mathrm{~m}$, for example, in the passages of the "Erectus Room." Parts of the "Michel," "White" and "Alto do T" Rooms are also at this level.

Along the active river course, the cave levels are generally represented as ghost passages or in the form of erosion levels, overlapping with several fossil passages in the canyon. In sectors A and B, the levels are distributed laterally in a northwesterly direction (Fig. 14A) due to canyon entrenchment and channel migration. In Sector $C$, the passages indicate the migration of the principal drainage channel and its junction with several tributaries, which results in a maze pattern (Palmer, 1975) with a high degree of structural control by the fractures (NW-SE) and foliation in the marble (Fig. 14B). In this sector, the morphology of the cave changes from a sinuous river passage to a labyrinthine pattern when all of the passages and levels are considered together in plan view. However, analysis of the river passage in Sector $\mathrm{C}$ alone reveals that it remains a sinuous river passage. In this sector, the large-scale collapses that have occurred in the upper passages (the Michel and White rooms) might have been responsible for the migration and diversion of the drainage channel.

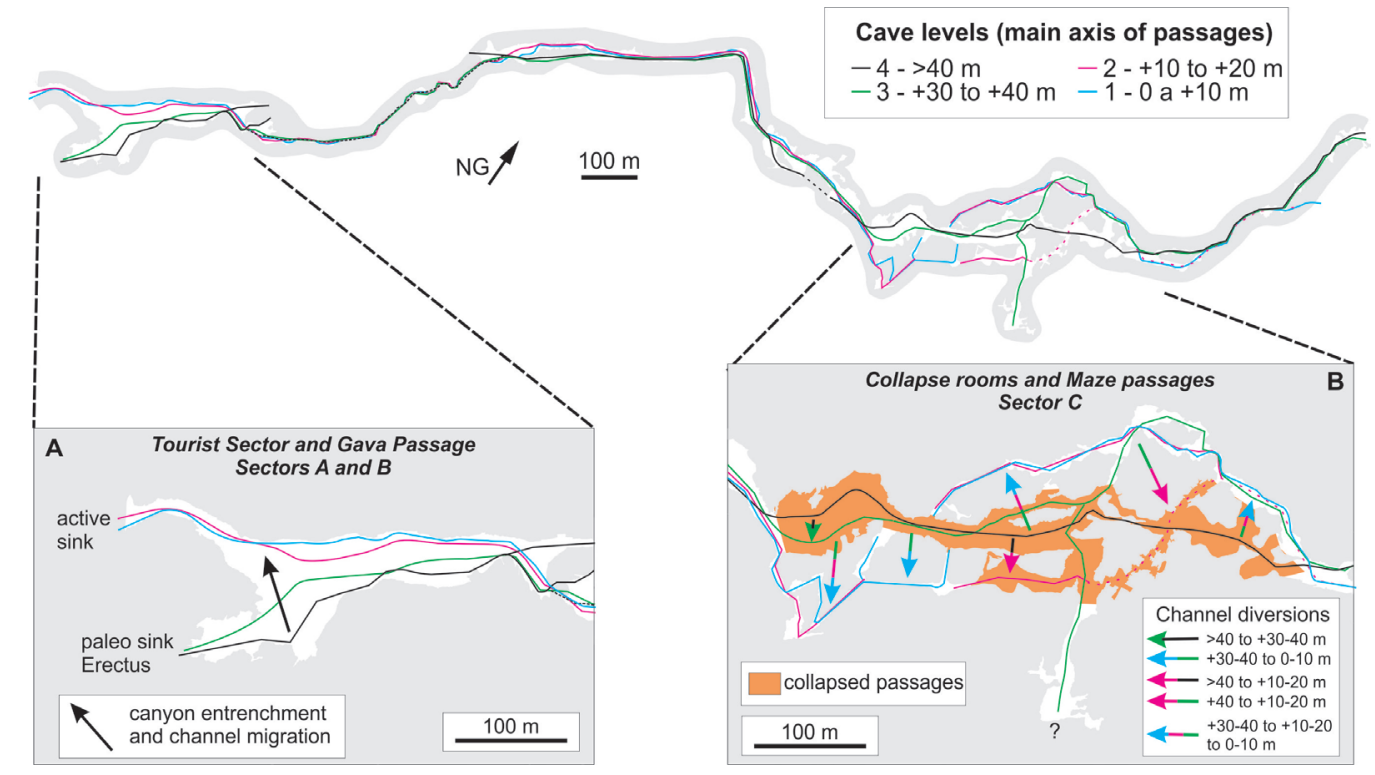

Fig. 14. Cave levels in plan view. The colored lines represent the main axis of the passages in each level. A) Detail of Sectors A and B; B) Detail of Sector C.

The Tapagem Marble is a long and narrow carbonate band, causing the marble to be an isolated, separate and confined aquifer. The synclinal structure with subjacent phyllites and the topographic situation of the carbonate plateau makes the karst a perched aquifer above the regional base level (the Ribeira River), with little allogenic recharge. The entire Tapagem Marble 
band has a combination of dolomitic composition, low degree of primary porosity and predominantly autogenic recharge $(86 \%)$, which results in a situation where there can be little development of caves. Caves are rare in the Tapagem Marble, so that Tapagem Cave is an anomaly. Its origin was possible due to the development of the Ostras River as a through valley and the allogenic recharge at the sink. Although the saturation index for calcite is positive, we believe that during flooding events, it can be negative. The cave originated in the narrowest portion of the marble band, a site favoring the injection of allogenic waters. The Tapagem River upstream of the cave has a very high hydraulic gradient over weathered non-carbonate rocks. Inside the cave, the river and the hydraulic gradient are also high. In addition to chemical corrosion, the river can transport clastic sediments, thus the effect of mechanical erosion on the enlargement of the conduits cannot be ignored.

The Tapagem and Ostras Rivers developed on a gentle surface draining to the Ribeira River: both cross the boundary of the marble at right angles. Progressively, the Ostras River formed a through valley at the surface because the allogenic surface runoff exceeded the capacity of the karst to absorb it (Ford \& Williams, 2007). With the entrenchment of the Ostras River, there was an accelerated decrease in the water table in this sector of the karst that was allowed for a higher amount of water infiltration. The Tapagem River was swallowed via the Erectus paleosink and formed an underground flow path (initiation phase) aided by the action of allogenic waters (Palmer, 2001).

In the initial stage, the Tapagem River remained in a half-blind valley (Monroe, 1970), a blind valley with a proportion overflowing seasonally into the Ribeira River, which marks the beginning of the drainage reorganization process via karstification (Williams, 1982). Increase in the efficiency of the underground drainage channel resulted in capture of more of the Tapagem River into the cave and its becoming a tributary of the Ostras River, the local base level of the karst aquifer in the northeastern sector of the plateau. Therefore, the Tapagem River lost volume at the surface, and the rate of entrenchment of the valley decreased. At this stage, the volume of water in the cave remained low, with a slow rate of erosion.

Following further enlargement of the conduits, the water absorption capacity increased in the cave and the entire drainage of the Tapagem River went underground. Significant collapses occurred in Sectors $\mathrm{A}$ and $\mathrm{C}$, however, because the action of the vadose water forming highly entrenched canyons induced extensive breakdown in the upper levels (White, 2005). The infiltration capacity decreased due to this obstruction of the passages by the collapse of the upper levels, and the drainage began to infiltrate at a new, lower sink (current) and develop new pathways.

Surface drainage once again reached higher volumes, favoring some surface overflow of the Tapagem River into the Ribeira River. In this stage, there was a long period of deposition of speleothems upon the collapsed blocks in the upper rooms.

When the drainage was able to infiltrate once again at the current sink in a more effective manner, the entire flow of the Tapagem River went underground with a permanent capture (beheading) of the drainage and the formation of the current blind valley. With increased flow underground, the rate of entrenchment of the vadose canyon was very high, causing lateral erosion of the passages and the collapse of a portion of the upper rooms and their speleothems. Flooding events, along with the predominance of coarse sediments on the riverbed, led to erosion through abrasion, giving rise to distinctive features such as potholes in stretches of rocky riverbed (Palmer, 2007), which are also favored by the steep gradient of the river and the hardness of the rock (Ford \& Williams, 2007).

The large pre-existing collapses in Sector C caused some diversions of the river, forming a maze pattern (Fig. 14B). The maze was created when the main passage was obstructed, and the stream divided into a network of bypasses that return to the main passage at several points (Palmer, 1975); collapsed blocks may obstruct the passages, breaking long, continuous conduits into various smaller, less efficient segments (White \& White, 2000). In Sector C, the river flows in the NE-SW and NW-SE directions, controlled by foliation in certain places and by fractures oriented in the same direction as the dykes in other places.

Considering the cave system evolutionary development model known as the "Four-State Model" (Ford \& Ewers, 1978; Ford, 2000), the Tapagem Cave is currently in the last evolutionary stage, Stage 4 (ideal water table caves). In a longitudinal section, it is possible to observe the remnants of loopings associated with the initial stages of the cave formation, currently carved by vadose entrenchment and filled with air, and low-ceiling sequences denoting the bypassing and filling of lower phreatic passages. Vadose inlet passages are infrequent, with only a few infiltration points for soil and gastropods, as in the example of the colluvialeluvial sediment deposits found in the "Cathedral Room," which is currently inactive due to surface relief inversion. The frequency of penetrable discontinuities is low and most likely did not increase with time beyond a level sufficient to create pathways able to drain all of the runoff in the basin. Additionally, the lowering of the base level is an important factor in the cave evolution and conduit development (Worthington, 2005). In Tapagem Cave, it is generally possible to observe vadose entrenchment passages. The canyon morphology of the cave is a product of passage enlargement by base level lowering and vadose entrenchment processes through the dissolution of the floor to a lower level (Ford \& Williams, 2007). In the process of opening up passages by vadose entrenchment, turbulent flow predominates, in which phreatic passages are entrenched and evolve into canyons with vertical walls (Palmer, 1991). Episodes involving a lowering of the base level of the karst are generally contemporaneous with surface geomorphological episodes (Powel, 1970). This underground morphology also occurs in the caves of other carbonate bodies in the Ribeira Valley, with canyons having entrenchments of up to $50 \mathrm{~m}$ because of lowering of the base level that was controlled by tectonic uplift (Karmann, 1994). With the exception of Sector C, few fossil passages are observed along the 
river passage, indicating a continuous entrenchment of the Ostras River Valley (Palmer, 1987).

The canyons found in Sectors A, B, and D are influenced by metamorphic banding in the Tapagem Marble, whereas in Sector C, the gradient of the Ribeira River to the NW controls the evolution of the vadose widening of the passages and, in certain situations, flows against the direction of the local hydraulic gradient, thus interrupting the bedrock structural controls.

The dykes create sectors with waterfalls and higher river gradient with greater erosive capacity. Several small rooms interrupt canyon formation along the river passage that could have been caused by the erosional resistance of the dykes during the initial phases, inducing flooding upstream of them and enlarging the rooms there.

\section{CONCLUSION}

Tapagem Cave, or Caverna do Diabo, is one of the most famous and most visited show caves in Brazil and is known for its scenic beauty, remarkable canyons and large speleothems. This cave is situated in a narrow and isolated band of dolomitic marbles.

The cave developed in a basin with $38.28 \%$ of allogenic recharge in a mixed system and in the greatest allogenic catchment area of the André Lopes karst. The creation of the cave was possible due to the development of the Ostras River as a through valley and the allogenic recharge at the sink.

The Tapagem River sank in the Erectus paleosink in a half-blind valley at the initial stages of cave formation and the entrenchment of the Ostras River. Although there is scarcely any matrix porosity in the marble, the metamorphic banding and the axial plane cleavage in an overall NE-SW direction exert an influence on the direction of the passages in plan view and their shape in cross-section. The synclinal structure exercises hydraulic control with a regional gradient to the Ribeira River to the NW, but the cave developed SE toward the Ostras River because of proximity to phyllites to the NW that function as an impermeable barrier. The cave is mostly controlled by marble banding, cleavage (NE-SW) and fractures (NW-SE). The cave has $6.3 \mathrm{~km}$ of passages in plan, including $2.84 \mathrm{~km}$ of the River Passage, a $2.8 \mathrm{~km}$ narrow, elongated and sinuous passage.

The action of vadose water creating highly entrenched canyons induced breakdown in the upper levels. The collapses led to obstruction of the early passages, causing the drainage to infiltrate at a new sink and develop new pathways. In due course the entire flow of the Tapagem River went underground, with a permanent capture beheading the drainage and the river downstream of it, forming the current blind valley. With a higher flow of water underground, the rate of entrenchment of the vadose canyon was very high, causing lateral erosion of the passages and the collapse by erosion of a portion of the upper rooms and their speleothems. In the River Passage, certain vadose canyons reach a height of $70 \mathrm{~m}$.

The maze pattern in the central part of the cave was created by dividing and bypassing the main passage due to obstruction by the collapse, which was strongly controlled by NE-SW foliation and by NW-SE fractures.

Intrusive dykes have been breached during the evolution of the cave, and variations in the hardness of the rock at them have led to the formation of several waterfalls and sectors with higher river gradients.

\section{ACKNOWLEDGEMENTS}

The authors thank the São Paulo Research Foundation FAPESP (Grant \#2011/10822-2) for financing the study and CNPq for the scholarships. We thank SBE and all of the PROCAD team for providing the cave map, COTEC for authorization of the activities in the park and CECAV for authorizing the rock sampling. We would like to thank Devil's Cave State Park for its support, particularly Josenei Cara and Mayra Jankowsky and all of the employees and monitors. We thank photographer Adriano Gambarini for the excellent photographs of the cave. Thanks are extended to all of the following colleagues for providing assistance in the field: Josias Moreira, Juliana Almeida, Jhonatas Moreira, Ladio Furquim, Marcos Silvério, Daniel Menin, Roberto Brandi, Valdomiro Pereira, Carlos Moraes, Luis Almeida, Rodrigo Borghezan, Tamires Zepon, Jonas Gallão, Bruno Consentino, Beatriz Boggiani and Bruna Torresi. We would also like to thank the Aristides of the Kaverna restaurant and the reviewers for their suggestions, especially Prof. Derek Ford for improving the text.

\section{REFERENCES}

Almeida F.F.M., 1964 - Fundamentos geológicos do relevo paulista. Boletim do Instituto Geográfico e Geológico, 41: 169-262.

Almeida F.F.M., 1977 - O Cráton de São Francisco. Revista Brasileira de Geociências, 7: 349-364.

Almeida F. F. M. \& Carneiro C.D.R., 1998 - Origem e Evolução da Serra do Mar. Revista Brasileira de Geociências, 28 (2): 135-150.

Alvares C.A., Stape J.L., Sentelhas P.C., Gonçalves J.L.M. \& Sparovek G., 2013 - Köppen's climate classification map for Brazil. Meteorologische Zeitschrift, 22 (6): 711-728.

http://dx.doi.org/10.1127/0941-2948/2013/0507

Brandi R. 2007 - Ricardo Krone e Lourenço Granato: Influências na história da espeleologia paulista no final do século XIX e início do século XX. O Carste, 19 (2): 36-60.

Campanha G.A.C., 1991 - Tectônica Proterozóica no Alto e Médio Vale do Ribeira, Estados de São Paulo e Paraná. Ph.D. thesis, Instituto de Geociências, Universidade de São Paulo, 296 p.

Campanha G.A.C., 2002 - O papel do sistema de zonas de cisalhamento transcorrente da porção meridional da Faixa Ribeira. Habil. thesis, Instituto de Geociências, Universidade de São Paulo, 105 p.

Campanha G.A.C. \& Sadowski G.R., 1999 - Tectonics of Southern portion of the Ribeira Belt (Apiai Domain). Precambrian Resarch, 98: 31-51. http://dx.doi.org/10.1016/S0301-9268(99)00027-3

Campanha G.A.C., Gimenes Filho A., Caetano S.L.V., Alves Pires F., Lucas Dantas A.S., Teixeira A.L., Dehira L.K., Hachiro J. \& Stefani F.L., 1985 - Geologia das folhas Iporanga (SG:22-X-B-V-2) e Gruta do Diabo (SG:22-X-B-VI-I). Estado de São Paulo, IPT/PróMinério. (Report n²2.352). 
CECAV, 2012 - Cavernas: Base de Dados Geoespacializados de Cavidades Naturais Subterrâneas do CECAV/ICMBIO, situação em Fevereiro de 2012.

http://www.icmbio.gov.br/cecav/downloads/mapas.html

Coutinho J.M.V., 2008 - Dyke Swarms of the Paraná Triple Junction, Southern Brazil. Revista Geologia USP, Série Científica, 8 (2): 29-52.

Despain J.D. \& Stock G.M., 2005 - Geomorphic history of Crystal Cave, Southern Sierra Nevada, California. Journal of Cave and Karst Studies, 67 (2): 92-102.

Ernesto M., Raposo M.I.B., Marques L.S., Renne P.R., Diogo L.A. \& Min, A., 1999 - Paleomagnetism, geochemistry and 40Ar/39Ar dating of the Northeastern Paraná magmatic province: tectonic implications. Journal of Geodynamics, 28 (4-5): 321-340.

http://dx.doi.org/10.1016/S0264-3707(99)00013-7

Faleiros F.M., Morais S.M. \& Costa V.S., 2012 - Unidades litoestratigráficas. In: Faleiros, F.M. \& Costa, V.S. (Orgs.). Geologia e recursos minerais da folha Apiai, SG.22-XB-V, estados de São Paulo e Paraná, Escala 1:100.000. CPRM, São Paulo, 107 p.

Faleiros F.M., Morais S.M. \& Costa V.S., 2013 - Unidades litoestratigráficas. In: Faleiros, F.M., Costa, V.S. (Orgs.). 2013 - Geologia e recursos minerais da folha Eldorado, SG.22-X-B-VI, estados de São Paulo e Paraná, Escala 1:100.000. CPRM, São Paulo, 128 p.

Figueiredo L.A.V., Zampaulo R.A., Geribello F.K., Pedro E.G., Dell'Antonio R. \& Lobo H.A.S., 2007 - Projeto Caverna do Diabo (PROCAD): Aspectos históricos (1990-2007) e resultados das expedições da terceira fase. In: Anais do XXIX Congresso Brasileiro de Espeleologia, Ouro Preto: 113-119.

Ford D.C., 2000 - Speleogenesis under unconfined settings. In: Klimchouk, A.V., Ford, D.C., Palmer A.N. \& Dreybrodt W. (Eds.), Speleogenesis: Evolution of Karst Aquifers. Huntsville: National Speleological Society: 319-24.

Ford D.C. \& Ewers R.O., 1978 - The development of limestone cave systems in the dimensions of length and depth. Journal of Speleology, 10: 213-244. http:/ /dx.doi.org/10.5038/1827-806X.10.3.1

Ford D.C. \& Williams P.W., 2007 - Karst Hydrogeology and Geomorphology. Wiley, Chichester, $561 \mathrm{p}$. http://dx.doi.org/10.1002/9781118684986

IGC 1988 - Cartas Topográficas do Instituto Geográfico e Cartográfico do Estado de São Paulo. Folha Córrego das Ostras (SG-22-X-B-VI-1-SO-B).

Karmann I., 1994 - Evolução e dinâmica atual do sistema cárstico do Alto Vale do Rio Ribeira de Iguape, sudeste do Estado de São Paulo. Ph.D. thesis, Instituto de Geociências, Universidade de São Paulo, 228 p.

Karmann I. \& Sanchez L.E., 1986 - Speleological Provinces in Brazil. In: Proceedings of 9th International Speleological Congress, Barcelona: 151-153.

Karmann I., Sánchez L.E., \& Fairchild T.R., 2001 - Caverna dos Ecos (Central Brazil): Genesis and geomorphologic context of a cave developed in schist, quartzite, and marble. Journal of Cave and Karst Studies, 63 (1): 41-47.

Krone R., 1898 - As grutas calcareas de Iporanga. Revista do Museu Paulista, 3: 477-500.

Krone R., 1904 - Grutas calcareas do Valle da Ribeira. Revista do Centro de Sciencias, Letras e Artes de Campinas, 2: 90-95.

Krone R., 1909 - Estudo sobre as cavernas do Valle do Ribeira. Arquivos do Museu Nacional, 15: 139-166.

Krüger M.V., 1967 - A gruta da Tapagem: II parte. Revista da Escola de Minas, Ouro Preto, 25 (4): 173-177.

Langmuir D., 1971. The Geochemistry of some Carbonate Groundwaters in Central Pensylvania. Geochimica Cosmochimica Acta, 35 (10): 1023-1045. http://dx.doi.org/10.1016/0016-7037(71)90019-6
Lauritzen S.E., 2001 - Marble stripe karst of the scandinavian caledonides: an end-member in the contact karst spectrum. Acta Carsologica, 30 (2): 47-79.

Le Bret M., 1966 - Estudos Espeleológicos no Vale do Alto da Ribeira. Boletim Instituto Geográfico e Geológico, 47: $71-123$.

Le Bret M., 1976 - Merveilleux Brésil Souterrain. Les Editions d'Octogone, Vestric, $235 \mathrm{p}$.

Leighton M.W. \& Pendexter C., 1962 - Carbonate rock types, in Ham, W.E., ed., Classification of carbonate rocks: Tulsa, USA, American Association of Petroleum Geologists, 1:33-61.

Lobo H.A.S., Trajano E., Marinho M.A., Bichuette M.E., Scaleante J.A.B., Scaleante O.A.F., Rocha B.N. \& Laterza F.V., 2013 - Projection of tourist scenarios onto fragility maps: Framework for determination of provisional tourist carrying capacity in a Brazilian show cave. Tourism Manangement, 35: 234-243. http://dx.doi.org/10.1016/j.tourman.2012.07.008

Martinet B. \& Sougy J., 1961 - Utilisation pratique des classications chimiques des roches carbonatées. Annales de la facultá dês sciences de 1`Université de Dakar, 6: 81-92.

Matos F.A., 1966 - A Gruta da Tapagem ("Caverna do Diabo"). Revista da Escola de Minas, 24 (3): 147-154.

Monroe W. H. (Compiler), 1970 - A Glossary of Karst Terminology. Geological Survey Water-Supply Paper 1899-K. U.S. Geological Survey. U.S. Government Printing Office, Washington, D.C., 26 p.

Palmer A.N., 1975 - The origin of maze caves. Bulletin of the National Speleological Society, 37 (3): 56-76.

Palmer A.N., 1987 - Cave leveIs and their interpretation. National Speleological Society Bulletin 49 (2): 50-66.

Palmer A.N., 1991 - Origem and morphology of limestone caves. Geological society of American Bulletin, 103: 1-21. http://dx.doi.org/10.1130/00167606(1991)103<0001:OAMOLC>2.3.CO;2

Palmer A.N., 2001 - Dynamics of cave development by allogenic water. Acta Carsologica, 30 (2): 14-32.

Palmer A.N., 2007 - Cave Geology. Cave Books, Dayton, 454 p.

Powel L.R., 1970 - Base level, lithologic and climatic controls of karst groundwater zones in South-central Indiana. Proceedings of Indiana Academy of Science, 79: 281-291.

Rauch H.W., White W.B., 1977 - Dissolution kinetics of carbonate rocks. 1. Effects of lithology on dissolution rate. Water Resources Research, 13 (2): 381-394. http://dx.doi.org/10.1029/WR013i002p00381

Renne P.R., Deckart K., Ernesto M., Feâraud G. \& Piccirillo E.M., 1996 - Age of the Ponta Grossa dike swarm (Brazil), and implications to Parana flood volcanism. Earth and Planetary Science Letters, 144 (1-2): 199-211.

http://dx.doi.org/10.1016/0012-821X(96)00155-0

Riccomini C., 1995 - Tectonismo gerador e deformador dos episódios sedimentares pós-gondvânicos da porção centro-oriental do Estado de São Paulo e áreas vizinhas. Habil. thesis, Instituto de Geociências, Universidade de São Paulo, 100 p.

Riccomini C., Sant'anna L.G. \& Ferrari A.L., 2004 Evolução geológica do rift continental do sudeste do Brasil. In: Mantesso-Neto V., Bartorelli A., Carneiro C. D. R. \& Brito-Neves B. B. (Eds.), Geologia do Continente Sul-Americano: Evolução da Obra de Fernando Flávio de Almeida. São Paulo: Beca: 383-405.

Sallun Filho W., Almeida L.H.S., Boggiani P.C. \& Karmann I., 2012 - Characterization of quaternary tufas in the Serra do André Lopes karst, southeastern Brazil. Carbonates and Evaporites, 27: 357-373.

http://dx.doi.org/10.1007/s13146-012-0118-1 
SBE - Sociedade Brasileira de Espeleologia, 2008 - Mapa da caverna do Diabo. Campinas: SBE.

White E.L., 2005 - Breakdown. In: Culver D. C \& White W.B, Encyclopedia of Caves. Burlington: Elsevier: 56-60.

White E.L. \& White W.B., 2000 - Breakdown Morphology. In: Klimchouk A.V., Ford D.C., Palmer A.N. \& Dreybrodt W. (Eds.), Speleogenesis: Evolution of Karst Aquifers. Huntsville: National Speleological Society: 427-429.
Williams P.W., 1982 - Karst landforms in New Zealand. In: Soons J. \& Selby M.J. (Eds.), Landforms of New Zealand. Auckland: Longman Paul: 105-125.

Worthington S.R.H., 2005 - Evolution of caves in response to base-level lowering. Cave and Karst Science, 32 (1): 3-12.

Zalán P.V. \& Oliveira J. A. B., 2005 - Origem e evolução estrutural do Sistema de Riftes Cenozóicos do Sudeste do Brasil. Boletim de Geociências Petrobrás, 13 (2): 269-300.

Zilio C., 2003 - Nas pegadas de Krone (1861-1918) - $1^{\circ}$ Parte. Informativo SBE, $\mathrm{n}^{\circ} 87$ : 25-26. 